\title{
Prevalence of Porcine Endogenous Retrovirus in Domestic Pigs in Japan and Its Potential Infection in Dogs Xenotransplanted with Porcine Pancreatic Islet Cells
}

\author{
Kazuya EDAMURA ${ }^{1,3)}$, Koko NASU $^{3)}$, Yukiko IWAMI ${ }^{3)}$, Ryohei NISHIMURA ${ }^{2)}$, Hiroyuki OGAWA ${ }^{1)}$, Nobuo SASAKI ${ }^{2)}$ \\ and Hisako OHGAWARA ${ }^{3)}$ \\ ${ }^{1)}$ Laboratories of Veterinary Emergency Medicine and ${ }^{2)}$ Veterinary Surgery, Graduate School of Agricultural and Life Sciences, The \\ University of Tokyo, 1-1-1 Yayoi, Bunkyo-ku, Tokyo, 113-8657 and ${ }^{3}$ Division of Cell Replacement and Regenerative Medicine, Medical \\ Research Institute, School of Medicine, Tokyo Women's Medical University, 8-1 Kawada-cho, Shinjyuku-ku, Tokyo, 162-8666, Japan
}

(Received 1 April 2003/Accepted 29 September 2003)

ABSTRACT. The prevalence of porcine endogenous retrovirus (PERV) proviral DNA among various pig breeds raised in Japan was investigated by polymerase chain reaction (PCR). Moreover, potential infection of PERV was investigated by PCR and reverse transcrip tasepolymerase chain reaction (RT-PCR) in experimentally induced diabetic dogs $(n=5)$ implanted with the diffusion chamber type bio-artificial endocrine pancreas (Bio-AEP) containing porcine pancreatic endocrine (PE) cells. No immunosupplessant was used after the transplantation. PERV gag, pol, env-A and $e n v$-B genes were detected in any pigs examined. In two of three Landrace breeds, env-C gene was absent. PERV proviral DNAs and viral RNAs were also detected from the cultured porcine PE-cells. In the peripheral blood $\mathrm{m}$ ononuclear cells and the spleen obtained at $6,30,32,36,79$ weeks of xenotransplantation in dogs, however, no evidence of microch imerism, infection and viremia were confirmed. These results suggested that the risk of PERV infection through xenotransplantation of Bio-AEP containing porcine islet cells without immunosuppressants may be quite low.

KEY WORDS: canine, diabetes, islet, porcine endogenous retrovirus (PERV), xenotransplantation.

J. Vet. Med. Sci. 66(2): 129-135, 2004

The pig is expected as the most suitable donor source of pancreas or islet xenotransplantation for the patients with insulin dependent diabetes mellitus. However, the risk of infection of porcine endogenous retrovirus (PERV) has been suggested in recent years [1]. PERV is classified into Family Retroviridae, Genus Gammaretrovirus [7]. PERV is related to other gammaretroviruses such as murine leukemia virus and feline leukemia virus in nucleotide and amino acid sequence and morphology, which may induce leukemia and immunodeficiency in the infected host, and potentially in recipients of xenotransplantation of porcine tissues [16].

Three classes of PERVs have been identified to date: PERV-A, -B and -C [5]. Most of xenozoonoses can be prevented by specific pathogen-free (SPF) breeding conditions and vaccination [16]. However, PERVs may be difficult to eliminate from porcine organs or tissues because multiple copies of PERV genomes are present in pig genomes [17]. The recent study showed that PERV particles could be released from PK-15 or porcine peripheral blood mononuclear cells (PBMCs) after mitogenic stimulation [5, 20].

In 1997, Patience et al. reported that PERV could infect human kidney 293 cells in vitro when the cells were co-cultured with PK-15 [14]. Moreover, van der Laan et al. demonstrated that when porcine pancreatic islets were transplanted into non-obese diabetic severe combined immunodeficiency (SCID) mice, PERV was transcriptionally active and infectious to them in vivo [19]. These results suggested that a concern for the risk of PERV infection associated with pig islet xenotransplantation might be justified.

Despite of potential transmittance of PERV to SCID mice by porcine islet transplantation, transmission of PERV has not been detected in baboons and human patients xenotransplanted or extracorporeally dialyzed with pig tissues $[3,6]$.

We have been studying xenotransplantation using a diffusion chamber for bio-artificial endocrine pancreas (BioAEP) containing porcine pancreatic endocrine (PE) cells [10]. In the previous study, xenotransplantation of Bio-AEP with porcine PE-cells into experimentally induced diabetic dogs was partially successful to reverse the hyperglycemic condition [4]. Clinical application of islet xenotransplantation may be possible in the future. Therefore, the risk of PERV infection must be investigated in the dog. However, there has been no information on the prevalence of PERV in various pig breeds raised in Japan or on in vivo investigation of PERV infection using dogs.

The purpose of this study was to investigate the prevalence of PERV proviral deoxyribonucleic acid (DNA) in pigs raised in Japan by polymerase chain reaction (PCR) using PERV specific primers reported from Centers for Disease Control and Prevention and Food and Drug Administration. Moreover, infection of PERV was investigated in dogs that had been xenotransplanted with Bio-AEP containing porcine PE-cells in the previous study by PCR and reverse transcriptase-polymerase chain reaction (RT-PCR).

\section{MATERIALS AND METHODS}

Pig and porcine PE-cells: Blood samples from the boars of Duroc $(n=3)$, Landrace $(n=3)$, Large Yorkshire $(n=3)$ and three-breed terminal crossbreed pigs $(n=3)$ were obtained from a pig breeding farm (Japan farm, Ltd., Kagoshima, Japan). These pig breeds occupy more than $95 \%$ of the pigs of Japan. PBMCs were used to investigate the prevalence of 
Table 1. Primer pairs and conditions for polymerase chain reaction (PCR) amplification of porcine endogenous retrovirus (PERV)

\begin{tabular}{|c|c|c|c|c|c|c|c|c|}
\hline No. & region & bps & primer & primer name & denature & annealing & replication & cycles \\
\hline (1) & gag & 187 & $\begin{array}{l}\text { CGGCAAGAGAAGAATTTGACTAAGATC } \\
\text { CAGTTCCTTGCCCAGTGTCCTCTT }\end{array}$ & $\begin{array}{l}\text { PRETF1 } \\
\text { PRETR1 }\end{array}$ & $94^{\circ} \mathrm{C}(60 \mathrm{~S})$ & $60^{\circ} \mathrm{C}(60 \mathrm{~S})$ & $72^{\circ} \mathrm{C}(60 \mathrm{~S})$ & 35 \\
\hline (2) & pol-1 & 212 & $\begin{array}{l}\text { CCACAGGGCAACGGCAGTATCCATG } \\
\text { TTGGAGGGTCAACACAGTGATGGG }\end{array}$ & $\begin{array}{l}\text { PK15GF2 } \\
\text { PK15GR2 }\end{array}$ & $94^{\circ} \mathrm{C}(60 \mathrm{~S})$ & $60^{\circ} \mathrm{C}(60 \mathrm{~S})$ & $72^{\circ} \mathrm{C}(60 \mathrm{~S})$ & 35 \\
\hline (3) & pol-2 & 116 & $\begin{array}{l}\text { AGCTCCGGGAGGCCTACTC } \\
\text { ACAGCCGTTGGTGTGGTCA }\end{array}$ & - & $94^{\circ} \mathrm{C}(60 \mathrm{~S})$ & $60^{\circ} \mathrm{C}(60 \mathrm{~S})$ & $72^{\circ} \mathrm{C}(60 \mathrm{~S})$ & 35 \\
\hline (4) & $e n v-\mathrm{A}$ & 320 & $\begin{array}{l}\text { TGGAAAGATTGGCAACAGCG } \\
\text { AGTGATGTTAGGCTCAGTGG }\end{array}$ & $\begin{array}{l}\text { PL170 } \\
\text { PL171 }\end{array}$ & $96^{\circ} \mathrm{C}(30 \mathrm{~S})$ & $55^{\circ} \mathrm{C}(45 \mathrm{~S})$ & $72^{\circ} \mathrm{C}(30 \mathrm{~S})$ & 30 \\
\hline (5) & $e n v-\mathrm{B}$ & 223 & $\begin{array}{l}\text { TTCTCCTTTGTCAATTCCGG } \\
\text { TACTTTATCGGGTCCCACTG }\end{array}$ & $\begin{array}{l}\text { PL172 } \\
\text { PL173 }\end{array}$ & $94^{\circ} \mathrm{C}(30 \mathrm{~S})$ & $55^{\circ} \mathrm{C}(45 \mathrm{~S})$ & $72^{\circ} \mathrm{C}(30 \mathrm{~S})$ & 30 \\
\hline (6) & $e n v-\mathrm{C}$ & 280 & $\begin{array}{l}\text { CTGACCTGGATTAGAACTGG } \\
\text { ATGTTAGAGGATGGTCCTGG }\end{array}$ & $\begin{array}{l}\text { PL205 } \\
\text { PL206 }\end{array}$ & $94^{\circ} \mathrm{C}(30 \mathrm{~S})$ & $58^{\circ} \mathrm{C}(45 \mathrm{~S})$ & $72^{\circ} \mathrm{C}(30 \mathrm{~S})$ & 30 \\
\hline
\end{tabular}

PERV proviral DNA.

PCR for porcine mitochondrial DNA and PERV proviral $D N A$ : Porcine PBMCs or PE-cells $\left(1.5 \times 10^{6}\right.$ cells each) were lysed with proteinase $\mathrm{K}$ at $70^{\circ} \mathrm{C}$ for $10 \mathrm{~min}$. Then, DNA was eluted using DNeasy ${ }^{\mathrm{TM}}$ Tissue system (QIAGEN Inc., Valencia, CA., U.S.A.). DNA was eluted in the elution buffer and used as a template of PCR. Porcine mitochondrial (mt) DNA cytochrome oxidase subunit II as a positive control of the porcine cell was amplified using primers PMTF2 and PMTR2 [3, 6]. PERV gag, pol, env-A, env-B and $e n v-\mathrm{C}$ specific amplifications were carried out with the previously reported primer pairs (Table 1) [3, 6, 18, 19]. PCR was performed on GeneAmp PCR System 2400 (Applied Biosystems, Foster City, CA., U.S.A.). The PCR enzyme used in this study was TaKaRa Ex Taq ${ }^{\mathrm{TM}}$ (Takara Shuzo Co., Ltd., Tokyo, Japan). The amplification conditions for PCR were shown in Table 1. Following electrophoresis on $1.8 \%$ agarose gels, PCR products were visualized by ultra violet irradiation after ethidium bromide staining.

Sensitivity of PCR for PERV proviral DNA was evaluated using cultured porcine PE-cells. The DNA concentration was measured with UV spectrophotometry and then serial diluted. The total DNA yields used in this study were $15 \mathrm{ng}, 1.5 \mathrm{ng}, 150 \mathrm{pg}$ and $15 \mathrm{pg}$, respectively.

Detection of PERV messenger ribonucleic acid (mRNA) from the cultured porcine PE-cells: The porcine PE-cells were isolated from the pancreas of crossbreed pigs. The isolation and the culture methods of PE-cells were the same as described in our previous study $[11,12,15]$. Porcine PEcells, which had been cultured at $37^{\circ} \mathrm{C}$ in atmosphere of $5 \%$ $\mathrm{CO}_{2}$ and $95 \%$ air for $1,3,6,9$ and 12 weeks, were used to investigate the expression of PERV mRNA. At the end of culture, porcine PE-cells were collected with ethylenediaminetetraacetic acid (EDTA) and trypsin (Invitrogen Co., Carlsbad, CA., U.S.A.). Then, porcine PE-cells were washed with cold $0.01 \mathrm{M}$ phosphate-buffered saline (PBS: Sigma Co. Ltd., St. Louis, MO., U.S.A.) and immediately immersed in TRIzol Reagent (Invitrogen Co.). The samples were incubated for $5 \mathrm{~min}$ at room temperature. Then, chloroform (Sigma Co., Ltd.) was added and centrifuged. Following centrifugation, the aqueous phase was transferred to the fresh tube. Then, isopropyl alcohol (Sigma Co., Ltd.) was added and centrifuged. The supernatant was removed, and the sediment was washed once with $75 \%$ ethanol by centrifugation. RNA samples were diluted with diethyl pyrocarbonate (DEPC: Sigma Co., Ltd.) treated ribonuclease (RNase)-free distilled water.

Recipients: Five Beagle dogs that had been transplanted with approximately 1.0 to $2.0 \times 10^{8}$ porcine PE-cells were used [4]. Porcine PE-cells were embedded in the diffusion chamber type Bio-AEP constructed of a silicon ring and two nucleopore membranes with a pore size of $0.1 \mu \mathrm{m}[4,10]$. Bio-AEP was implanted into the abdominal cavity of the dog without fixation. No immunosuppressive drug was used in the experiment.

Detection of PERV proviral DNA in the recipients: PBMCs and the spleen of dogs were collected at autopsy at $6,30,32,36,79$ weeks of implantation for the detection of PERV proviral DNA. PBMCs were purified by Histopaque 1077 (Sigma Co., Ltd.) layer centrifugation at room temperature immediately after collection. These samples were soaked in liquid nitrogen immediately after purification, and stored at $-70^{\circ} \mathrm{C}$ until PCR or RT-PCR was performed. After thawing the sample, DNAs of PBMCs and the spleen of the recipients were lysed as described above. Canine GAPDH primer pairs (sense: 5'-CTCATGACCACAGTCCATGC3', antisense: 5'-TGAGCTTGACAAAGTGGTCA-3') were used for positive marker for PCR and RT-PCR. The sample was amplified using primers specific for porcine mtDNA to investigate microchimerism, and primers specific for PERV gag, pol, env-A, env-B and $e n v-\mathrm{C}$ to survey infection. The PCR conditions were the same as described above (Table 1). All examinations were performed at least 4 times using the different concentration of DNA or mRNA to check reproducibility.

cDNA synthesis and RT-PCR to detect PERV mRNA: The frozen samples from dog recipients were removed from $-70^{\circ} \mathrm{C}$ and immediately homogenized in TRIzol Reagent. The RNA elution method was the same as described above. All RNA samples were treated with deoxyribonuclease I (DNase I Amp Grade, Invitrogen Co.) to prevent them from contamination of genomic DNA. After the treatment, cDNA synthesis was performed using the ThermoScript 
RT-PCR system (Invitrogen Co.). RNA ( $1 \mu \mathrm{g})$ and Oligo $(\mathrm{dT})_{20}$ were used to synthesize cDNA. RNase $\mathrm{H}$ was added to completely remove RNA after cDNA synthesis. The cDNA was amplified using primers of PERV gag, pol, env$\mathrm{A}, e n v-\mathrm{B}, e n v-\mathrm{C}$ and canine GAPDH. The PCR conditions were shown in Table 1.

\section{RESULTS}

PCR for porcine mtDNA was still positive with $15 \mathrm{pg}$ of DNA of porcine PE-cells. PERV gag and pol proviral DNAs could also be detected from only $15 \mathrm{pg}$ of DNA.
PCR for PERV gag or pol was more sensitive than for envA, $e n v-\mathrm{B}$ and $e n v-\mathrm{C}$ (Fig. 1).

All the pig breeds investigated had PERV gag, pol, env-A and $e n v$-B genes (Fig. 2). In two of three Landrace breeds, $e n v-\mathrm{C}$ gene was absent, while $e n v-\mathrm{C}$ gene was detected in other breeds (Fig. 2).

PERV proviral DNAs were also detected in cultured porcine PE-cells. When the change in the expression during the culture period of porcine PE-cells was evaluated, PERV gag and pol RNAs were detected from porcine PE-cells cultured for 1, 3, 6, 9 and 12 weeks (Fig. 3).

After implantation of Bio-AEP into diabetic dogs, no

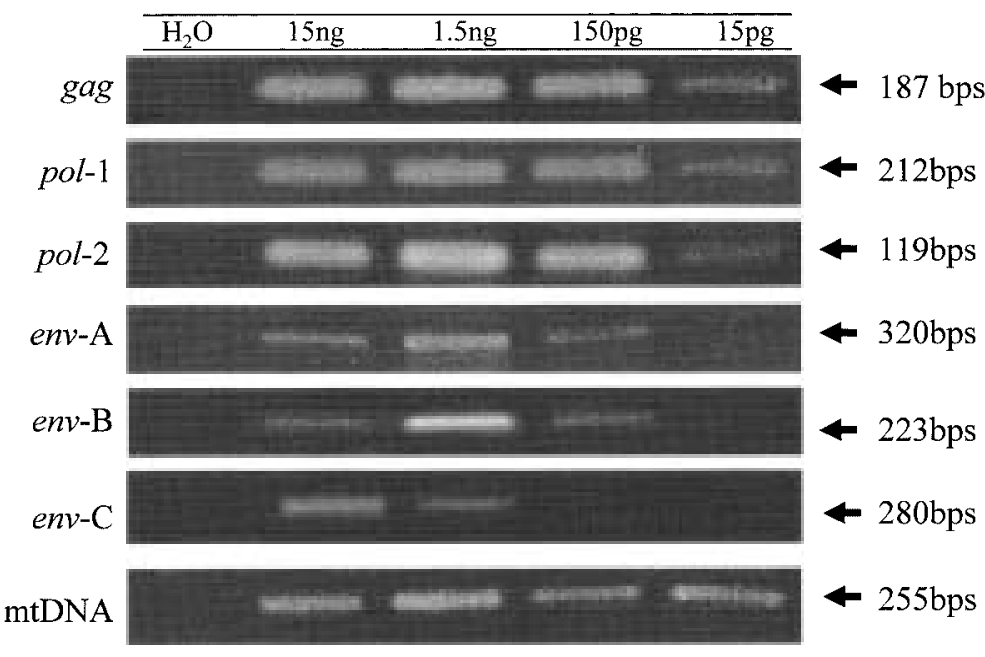

Fig. 1. Sensitivity analysis of porcine mitochondrial (mt) DNA and porcine endogenous retrovirus (PERV) proviral deoxyribonucleic acid (DNA) in cultured porcine pancreatic endocrine (PE) cells.

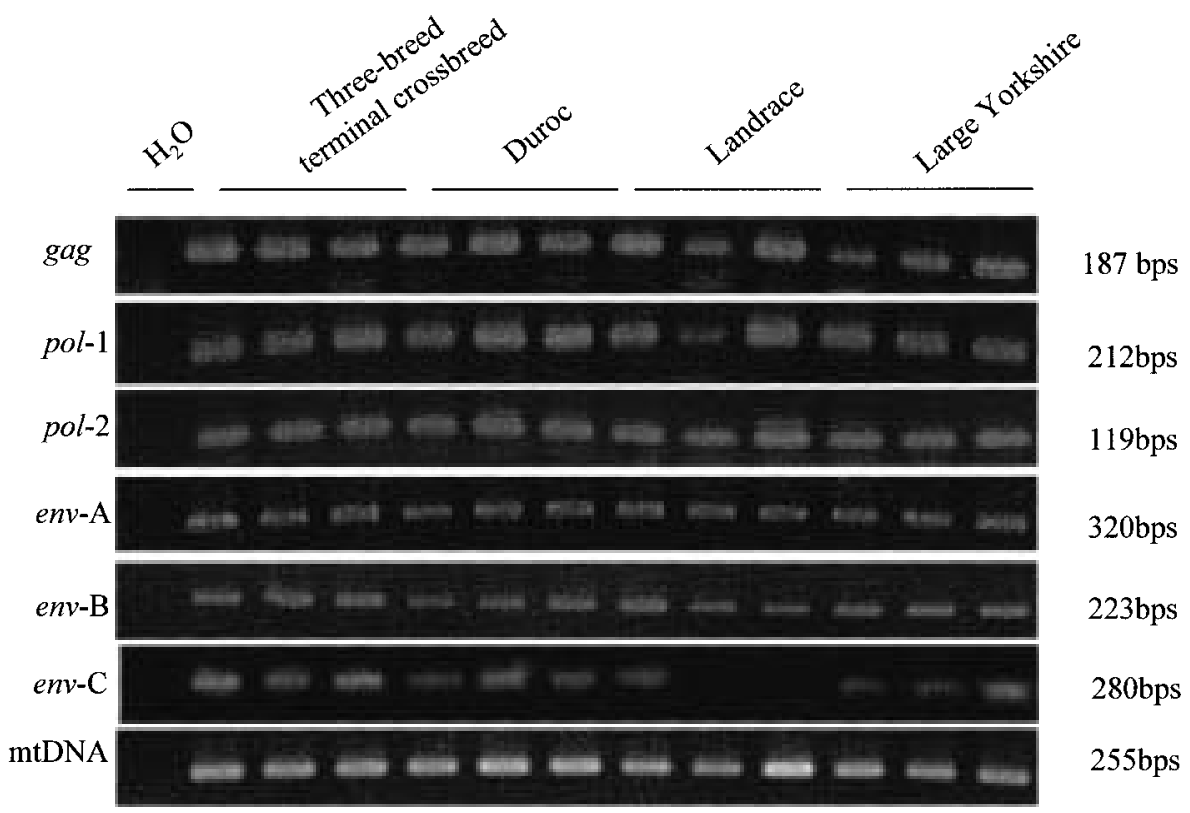

Fig. 2. Polymerase chain reaction (PCR) analysis of peripheral blood mononuclear cells (PBMCs) from each breed of pigs for PERV gag, pol, env proviral DNA and porcine mtDNA sequences. 


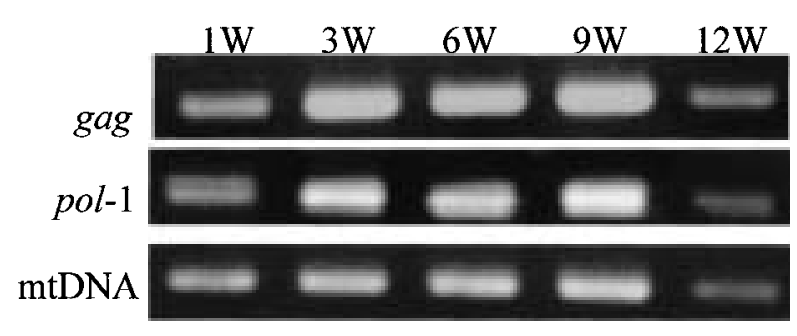

Fig. 3. Reverse transcriptase (RT) -PCR analysis of cultured porcine PE-cells for PERV gag, pol and porcine mtDNA sequences. PERV gag and pol messenger ribonucleic acids (mRNAs) were detected in porcine PE-cells cultured for 1, 3, 6, 9 and 12 weeks. recipient had signs of lymphoproliferative or neurological diseases associated with gammaretroviruses. Figures 4 and 5 show the results of PCR and RT-PCR in PBMCs and the spleen of recipient dogs. Porcine mtDNA was also not detected in any samples of the recipients. Therefore, microchimerism was not confirmed in all recipients of this study after xenotransplantation. All PERV proviral DNAs and mRNAs were not detected in any PBMCs and the spleen of the recipients, suggesting no evidence of infection and viremia of PERV in recipients after xenotransplantation of BioAEP.

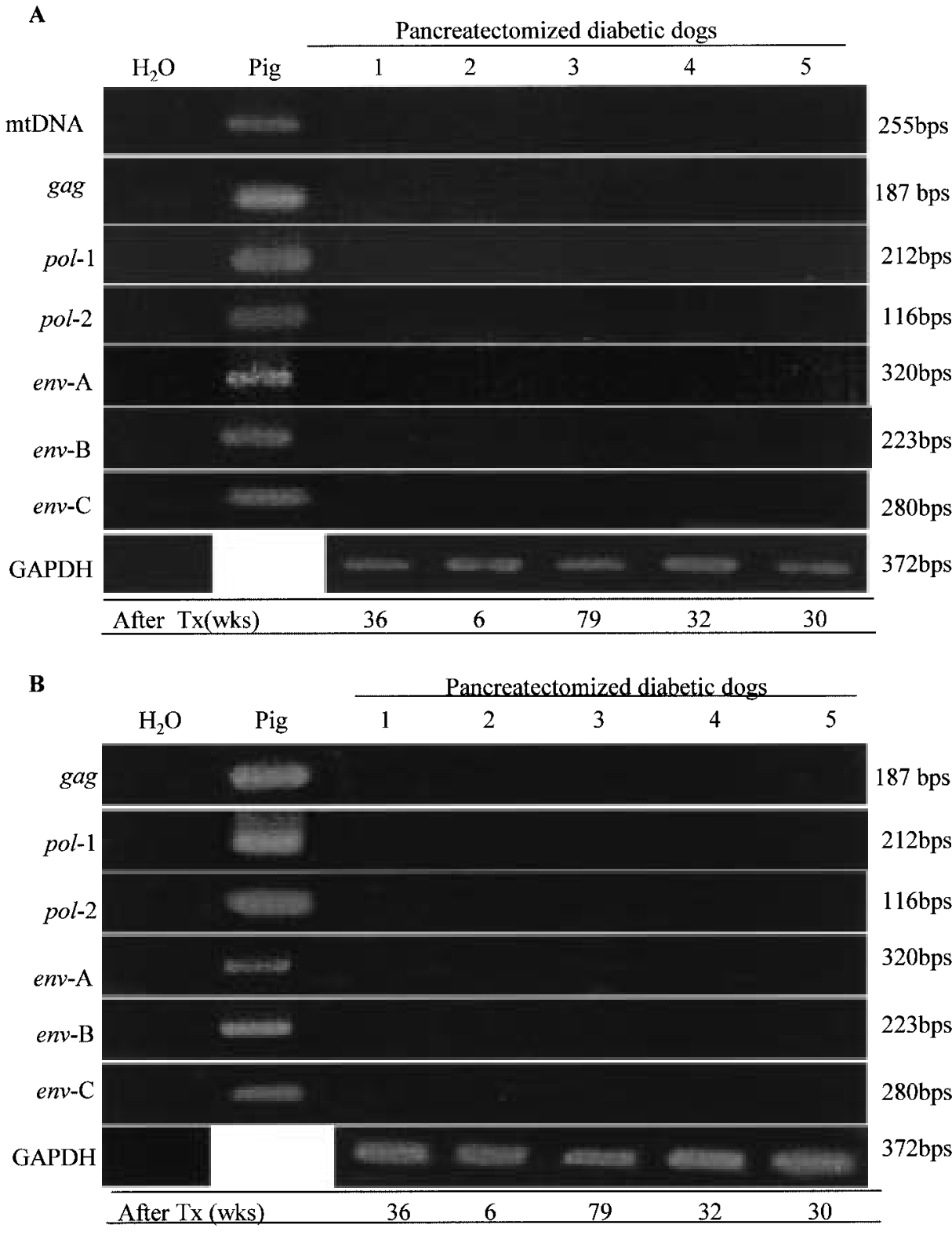

Fig. 4. Detection of PERV DNA and mRNA, and porcine mtDNA in PBMCs of dogs implanted with bioartificial endocrine pancreas (Bio-AEP). (A) PERV DNA sequences and porcine mtDNA were undetectable by PCR. (B) PERV mRNA was also undetectable by RT-PCR. After Tx: After transplantation. 
A
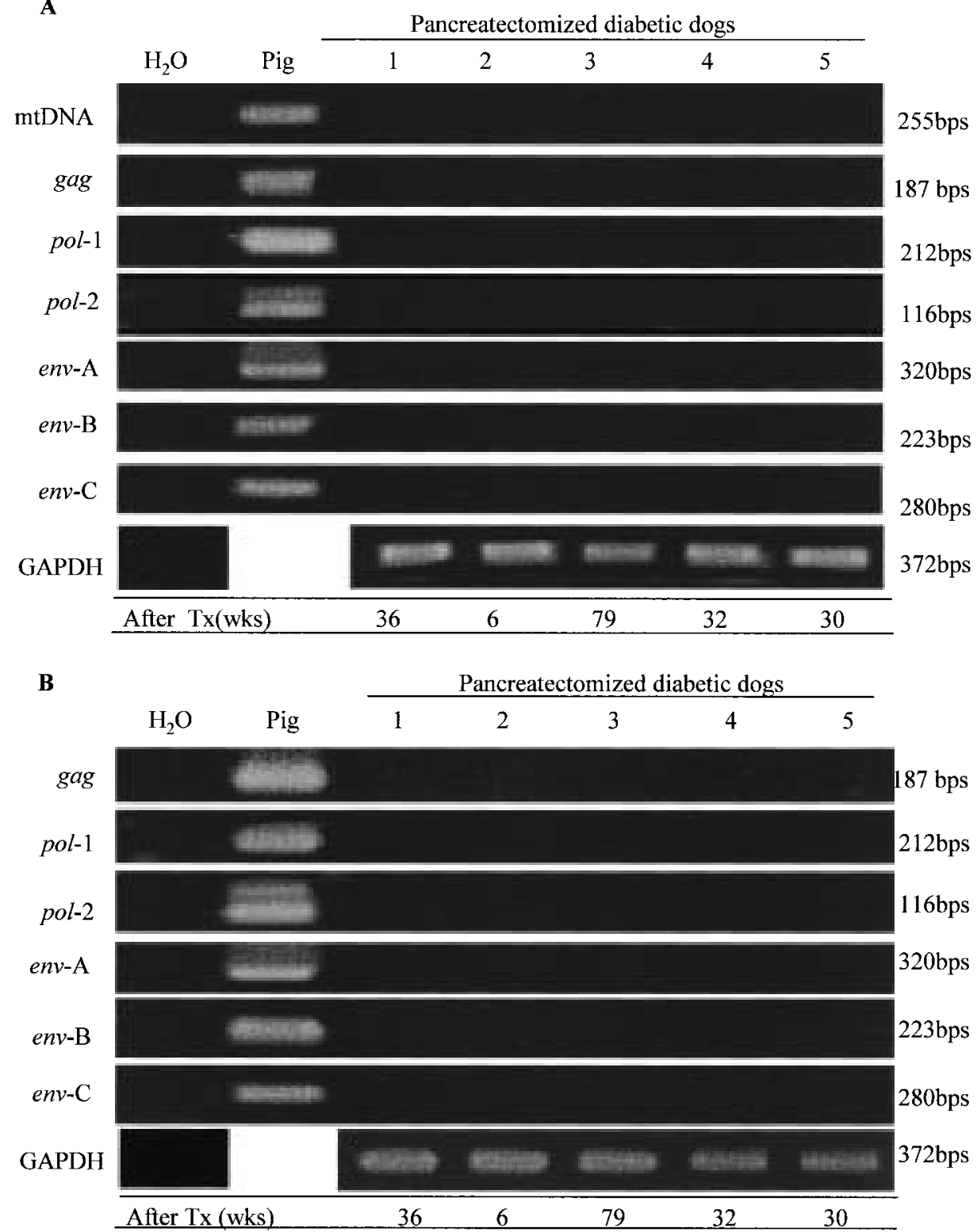

Fig. 5. Detection of PERV DNA and mRNA, and porcine mtDNA in the spleen of dogs implanted with Bio-AEP. (A) PERV DNA sequences and porcine mtDNA were undetectable by PCR. (B) PERV mRNA was also undetectable by RT-PCR. After Tx: After transplantation.

\section{DISCUSSION}

All the pigs of any breeds investigated in this study had PERV proviral DNAs, suggesting wide prevalence of PERV in pigs of Japan. The surveillance of PERV in the pig before xenotransplantation of porcine PE-cells was possible by measuring using PBMCs. In two of three Landrace breeds, env $\mathrm{C}$ gene was absent. Bösch et al. also reported env $\mathrm{C}$ gene was absent in some of SPF Large White pigs [2]. However, env A and $e n v \mathrm{~B}$ genes were recognized in all pigs examined. One option to prevent from infection may be to use PERV-free pigs that generated by knocking out or disrupting crucial PERV genes.

Cultured porcine PE-cells were also recognized PERV proviral DNAs. In this study, PERV gag and pol proviral DNA could be detected from only $15 \mathrm{pg}$ of DNA of the PEcells, thus PCR is highly sensitive for the molecular detection of the PERV sequence and could be clinically applicable. The expression of mRNA for PERV was detected from porcine PE-cells even after 12 weeks of culture, suggesting that PERV mRNA could be released from cultured porcine PE-cells without mitogenic stimulation by concanavalin $\mathrm{A}$ 
(ConA), phytohemagglutinin (PHA) and phorbol myristate acetate (PMA). Clemenceau et al. reported that PERV gag, pol, and env mRNA were found in pig islet cells, but full length genomic PERV mRNA and RT-activity were not detected [3]. From the results of this study, complete PERV virions might not be released from porcine PE-cells as shown in the report by Clemenceau et al. Therefore, PERV infection might not be confirmed in this experiment despite the expression of PERV mRNAs in the cultured porcine PEcells.

In the recent investigation, 17 of 25 SCID mice were positive for mtDNA and PERV pol when porcine islets were transplanted under the kidney capsules [19]. In that report, the organ most frequently infected with PERV was the spleen. Therefore, the spleen was examined in this study, however, PERV proviral DNA and mRNA sequences were not detected in the spleen of any recipients.

The diffusion chamber type Bio-AEP used in this study had two nucleopore membranes with a pore size of $0.1 \mu \mathrm{m}$. In the previous studies, PERV RNAs were small enough to cross the pores in the membrane of $70 \mathrm{kDa}$ nominal molecular weight cut-off (MWCO) (estimated to be $5 \mathrm{~nm}$ ). However, PERV was unable to infect 293 cells cultured in the extraluminal space isolated by fibers $<400 \mathrm{kDa}$ MWCO, while PERV particles could cross the membrane with a pore size of $0.2 \mu \mathrm{m}$ and infect 293 cells [8,9]. The diameter of PERV is approximately $0.1 \mu \mathrm{m}$ according to electron microscopy [20]. Therefore, PERV particles might pass through the membrane of the Bio-AEP. Unfortunately, it was not confirmed whether PERV particles could across the membrane in this study.

To our knowledge, there has been only one report on PERV infection in vivo [19], where SCID mice were used and authors stated that the risk of PERV infection may be significantly increased in the patient with severe immunodeficiency or the patient medicated with immunosuppressive drugs. However, no infection and viremia was detected in 160 patients transplanted with living porcine tissues or cells with immunosuppressants [13]. In his report, persistent microchimerism was observed in 23 of 159 patients, where 23 patients were treated with extracorporeal splenic perfusion [13]. This result may suggest that the risk of PERV infection is significantly increased in the patient with vascular anastomosis.

The receptor of PERV on the cell is important for establishment of PERV infection. It has been suggested that canine cells have the receptor [17]. These results suggest that PERV is not easily transmitted to dogs through this type of xenografts.

In conclusion, it is suggested that the risk of PERV infection through the implantation of Bio-AEP containing porcine PE-cells without immunosuppression and vascular anastomosis may be quite low. It may be possible to detect PERV infection by using currently available techniques. Our strategy of embedding porcine PE-cells within a diffusion chamber may be advantageous in respect of PERV infection, however further researches will be needed to clar- ify more precisely the potential infection of PERV to the recipient dogs.

ACKNOWLEDGEMENTS. This study was supported, in part, by a Grant-in-Aid for Scientific Research (B; 11480260), the program for Promotion of Fundamental studies in Health Sciences of the Organization for Pharmaceutical Safety and Research, and Creative Basic Research (10NP0201) from the Ministry of Education, Science, and Technology of Japan.

\section{REFERENCES}

1. Butler, D. 1998. Last chance to stop and think on risks of xenotransplants. Nature (Lond.) 391: 320-328.

2. Bösch, S., Arnauld, C. and Jestin, A. 2000. Study of full-length porcine endogenous retrovirus genomes with envelope gene polymorphism in a specific-pathogen-free large white swine herd. J. Virol. 74: 8575-8581.

3. Clemenceau, B., Jegou, D., Martignat, L. and Sai, P. 2001. Long-term follow-up failed to detect in vitro transmission of full-length porcine endogenous retroviruses from specific pathogen-free pig islets to human cells. Diabetologia 44: 2044-2055.

4. Edamura, K., Itakura, S., Nasu, K., Iwami, Y., Ogawa, H., Sasaki, N. and Ohgawara, H. 2003. Xenotransplantation of porcine pancreatic endocrine cells to total pancreatectomized dogs. J. Vet. Med. Sci. 65: 549-556.

5. Fiane, A. E., Mollnes, T. E. and Degre, M. 2000. Pig endogenous retrovirus -a threat to clinical xenotransplantation? Acta Pathol. Microbiol. Immunol. Scand. 108: 241-250.

6. Heneine, W., Tibell, A., Switzer, W. M., Sandstrom, P., Rosales, G. V., Mathews, A., Korsgren, O., Chapman, L. E., Folks, T. M. and Groth, C. G. 1998. No evidence of infection with porcine endogenous retrovirus in recipients of porcine islet-cell xenografts. Lancet 352: 695-699.

7. Klymiuk, N., Muller, M., Brem, G. and Aigner, B. 2002. Characterization of porcine endogenous retrovirus gamma pro-pol nucleotide sequences. J. Virol. 76: 11738-11743.

8. Kuddus, R., Patzer, J. F., Lopez, R., Mazariegos, G. V., Meighen, B., Kramer, D. J. and Rao, A. S. 2002. Clinical and laboratory evaluation of the safety of a bioartificial liver assist device for potential transmission of porcine endogenous retrovirus. Transplantation 73: 420-429.

9. Nyberg, S. L., Hibbs, J. R., Hardin, J. A., Germer, J. J. and Persing, D. H. 1999. Transfer of porcine endogenous retrovirus across hollow fiber membranes. Transplantation 67: 12511255.

10. Ohgawara, H. 2000. Strategies for immunoisolation in islet transplantation: challenges for the twenty-first century. $J$. Hepatobiliary Pancreat. Surg. 7: 374-379.

11. Ohgawara, H., Kobayashi, A., Chong, S. J., Akaike, T. and Hashimoto, Y. 1994. Preparation of adult pig pancreatic cells: comparative study of methods with or without proteolytic enzymes. Cell Transplant. 3: 325-331.

12. Ohgawara, H., Shikano, T., Fukunaga, K., Yamagishi, M. and Miyazaki, S. 1998. Establishment of monolayer culture of pig pancreatic endocrine cells by use of nicotinamide. Diabetes Res. Clin. Pract. 42: 1-8.

13. Paradis, K., Langford, G., Long, Z., Heneine, W., Sandstrom, P., Switzer, W. M., Chapman, L. E., Lockey, C., Onions, D. and Otto, E. 1999. Search for cross-species transmission of 
porcine endogenous retrovirus in patients treated with living pig tissue. Science 285: 1236-1241.

14. Patience, C., Takeuchi, Y. and Weiss, R. A. 1997. Infection of human cells by an endogenous retrovirus of pigs. Nat. Med. 3: 282-286.

15. Sato, S., Ohgawara, H., Katagiri, N., Nakagawa, Y., Aikawa, E., Omori, Y. and Ota, K. 1996. A novel, simple method for purification of adult pig pancreatic endocrine cells. J. Tokyo Wom. Med. Coll. 66: 471-479.

16. Tacke, S. J., Kurth, R. and Denner, J. 2000. Porcine endogenous retroviruses inhibit human immune cell function: risk for xenotransplantation? Virology 268: 87-93.

17. Takeuchi, Y., Patience, C., Magre, S., Weiss, R. A., Banerjee, P. T., Tissier, P. L. and Stoye, J. P. 1998. Host range and inter- ference studies of three classes of pig endogenous retrovirus. $J$. Virol. 72: 9986-9991.

18. Tissier, P. L., Stoye, J. P., Takeuchi, Y., Patience, C. and Weiss, R. A. 1997. Two sets of human-tropic pig retrovirus. Nature (Lond.) 389: 681-682.

19. van der Laan, L. J. W., Lockey, C., Griffeth, B. C., Frsier, F. S., Wilson, C. A., Onions, D. E., Hering, B. J., Long, Z., Otto, E., Torbett, B. E. and Salomon, D. R. 2000. Infection by porcine endogenous retrovirus after islet xenotransplantation in SCID mice. Nature (Lond.) 407: 90-94.

20. Wilson, C. A., Wong, S., Muller, J., Davidson, C. E., Rose, T. M. and Burd, P. 1998. Type C retrovirus released from porcine primary peripheral blood mononuclear cells infects human cells. J. Virol. 72: 3082-3087. 